\title{
Between Theological Ideals and Empirical Realities: Complex Diversity in Interreligious Dialogue
}

\section{A Catholic Perspective}

\author{
Regina Polak \\ Associate Professor, Institute for Practical Theology, Catholic-Theological \\ Faculty, University of Vienna, Vienna, Austria \\ regina.polak@univie.ac.at
}

\begin{abstract}
Empirical research on the practice of interreligious dialogue delivers inspiring results for a practical-theological reflection. The contribution thus discusses the question of what theological and social science research can learn from each other. The author presents four exemplary theses on the Catholic understanding of the nature, aims and methods of interreligious dialogue, and puts them into a mutual dialogue with the empirical results of this study. The results demonstrate that interreligious dialogue only exists within different social and political contexts that should be recognised theologically as "incarnated" forms of dialogue. The diverse social and political functions of interreligious dialogue can be interpreted as dimensions of the evangelizing mission of the Church. In turn, social science research on interreligious dialogue should take "inside" dimensions into academic consideration such as aspects of theological self-understanding, the question of truth or the missionary dimension of interreligious dialogue.
\end{abstract}

\section{Keywords}

interreligious dialogue - interdisciplinarity - mission - religious plurality

In the first session of my lecture on interreligious dialogue, I try to sensitize my students to the difference between the theological foundations, motivations, 
and objectives of dialogue and the empirical reality they will face in their pastoral work. They learn that people entering interreligious dialogue argue their interests in dialogue usually quite differently from what the respective doctrines and rules of the Churches and religious institutions and communities prescribe.

In his empirical study "Religion on the move", Martin Rötting presents six different "dialogue-types" when practicing interreligious dialogue: the "spiritual pilgrim", the "social mover", the "religious-cultural democrat", the "cultural harmonizer", the "orthodox adaptor" and the "humanitarian religious". ${ }^{1}$ For my contribution it is not necessary to describe these types in detail, but to highlight one of the results: Christians, Muslims, Jews, and Buddhists could be found in each of these types, which means that they refer to diverse arguments, motives and aims that are not always in line with the respective self-understanding of their religious affiliation. An example: Whereas the "orthodox adaptor" aims at protecting the doctrines, traditions and rites of his own religion from mixing with elements of other religious traditions, the "humanitarian religious" strives for the inclusion of different religious teachings into a universal form of religion that excludes no one else. Christians can be found in both types, which results in conflicts between them, as one can imagine. Moreover, from a Catholic view, "humanitarian religious" motives contradict the Catholic doctrine, as we will see.

These observations are relevant, as they demonstrate the gap between theological ideals and empirical realities - a gap, which is the starting point for a practical-theological reflection on the topic of this issue. Pastoral work must not only deal with this gap but recognize it as a reality with respective theological dignity. This means that the empirical reality is a so-called locus theologicus, ${ }^{2}$ e.g. a space that theological experience and knowledge can be derived from. The social science findings on interreligious dialogue throughout Europe presented in this issue ${ }^{3}$ can be considered such a locus theologicus as well. The findings provide insight into the social and political dimensions of interreligious dialogue and can support practical theology to reflect and improve practice of dialogue in the pastoral realm. In my article I will reflect the findings of the symposium ${ }^{4}$ from a practical-theological perspective. The leading research question thus is: What can Practical Theology learn from the

1 Rötting, Religion in Bewegung, pp. 93-116.

2 Polak, Migration als Ort der Theologie, pp. 69-77.

3 Lehmann, Interreligious Dialogue in Context.

4 Symposium: "Interreligious Dialouge in Context: A European Comparison". 17.10. - 19.10.2019, Vienna. 
social science findings on interreligious dialogue in Europe for its practice and theology of interreligious dialogue? Vice versa, what can social science learn from a theological approach?

As every religious tradition has its specific theological foundation and definitions of interreligious dialogue, ${ }^{5} \mathrm{I}$ will concentrate on a Catholic approach.

I will answer the above stated question in three steps. First, I will explicate the Catholic doctrine of the essence, nature, aims, and motives on interreligious dialogue by presenting four exemplary theses. These theses are the framework for the second step, a mutual dialogue with the empirical research findings of this issue of JRAT. Finally, in the third step I will present some future perspectives that should be taken into consideration in further interdisciplinary research on interreligious dialogue.

\section{Interreligious Dialogue from the Perspective of Catholic Doctrine}

Compared to other religions, the Catholic Church is the only religious institution worldwide that provides an official mandatory doctrine on interreligious dialogue for its believers. However, that does not mean that there is no debate on the essence and aims of interreligious dialogue. On the contrary, since the Second Vatican Council - the starting point of a new theological recognition of the diversity of religions ${ }^{6}$ - the development of the Catholic doctrine was accompanied by intensive and conflictive debates on the theological interpretation of the plurality of religions. As a Catholic theologian I can refer to decades of differentiated theological reflections on interreligious dialogue both ecclesial and theological.

As it is impossible to present this rich tradition here, I will concentrate on the widely accepted status quo of the Catholic doctrine without going into detail of the theological conflicts and disagreements. I will formulate four theological theses on interreligious dialogue that are helpful for my purpose to compare a theological and an empirical approach. To make the difference between these approaches more visible, I deliberately chose theses that are quite unknown in the realm of social science. They will differ from the usual empirical understanding of interreligious dialogue. However, in my experience, reflecting on differences can generate more knowledge than focusing on similarities.

5 Ulrich et al., Handbuch Theologie der Religionen.

6 Cf. Renz, Die katholische Kirche und der interreligiöse Dialog. 

Nature and the Essence of the Church

In the encyclical Ecclesiam suam (1964), ${ }^{7}$ the so-called "Magna Charta" of dialogue, Pope Paul vi defined the Church as Dialogue. He claimed that the Church must enter dialogue with the world in which it lives, because Church can realize itself only through dialogue. Church is dialogue as such. Dialogue is thus not only a recognized method of the Church, but the way it concretizes its mission. Dialogue is the nature and the essence of the Church. This position is argued theologically:

God Himself took the initiative in the dialogue of salvation. 'He hath first loved us.' (1 Jn 4:10) We, therefore, must be the first to ask for a dialogue with men, without waiting to be summoned to it by others. The dialogue of salvation sprang from the goodness and the love of God. 'God so loved the world as to give His only begotten Son.' (1 Jn 3:16) Our inducement, therefore, to enter into this dialogue must be nothing other than a love which is ardent and sincere. ${ }^{8}$

The encyclical states that dialogue must never be limited, that it must never seek self interests nor be coercive. It is God who initiated dialogue Godself to establish a relationship with mankind. Dialogue is the "method" of salvation. It is the Lord's practice. Therefore, as imago Dei the human nature can and must be realized also dialogically. Consequentially, Catholics have the duty to enter into dialogue with the world.

The understanding of the Church as a dialogical institution is the fundamental signature of the documents of the Second Vatican Council. Since then, the Church is committed to dialogue within and outside. In the Pastoral Constitution on the Church in the Modern World Gaudium et Spes (1965), ${ }^{9}$ dialogue is addressed with regard to different groups. GS n. 3, n. 40, n. 85 , n. 9o, and n. 92 oblige the Church to dialogue with all human beings, GS n. 93 refers to dialogue with the world. The Decree Ad Gentes on the Mission Activity of the Church, ${ }^{10}$ n. 16 and n. 34, challenges the Church to enter dialogue with non-Christians. Finally, Nostra Aetate, the Declaration on the Relation of the Church to Non-Christian Religions (1965), ${ }^{11}$ opens interreligious dialogue to all

\footnotetext{
$7 \quad$ Ecclesiam Suam (ES).

$8 \quad E_{72-74}$

$9 \quad$ Gaudium et Spes (GS).

10 Ad Gentes $(A G)$.

11 Nostra Aetate (NAe).
} 
other religions. In the aftermath of the Second Vatican Council, it was John Paul II, who formulated decisive points for a theological understanding of interreligious dialogue that cannot be overestimated for the progress in this issue. He argued that the Holy Spirit itself is the origin and the source of contemporary interreligious dialogue. ${ }^{12}$

Therefore, from a Catholic point of view, contemporary interreligious dialogue is not just a reaction towards religious pluralization, secularization or migration. Rather, it is a duty for all Catholic Christians that must be fulfilled even if no members of other religions lived in their country or neighbourhood. Catholics would have to deal with the scriptures of other religious traditions then. Interreligious dialogue may have pragmatic reasons, but theologically it is an end and a normative practice prescribed to the believers. It has ethical, spiritual and theological foundations. This shall be demonstrated exemplary by two Catholic statements. In 1986, John Paul II addressed the people in Madras (India): "By opening ourselves to the other in dialogue we open ourselves to God."13 On the 34th General Congregation Assembly of the Jesuit congregation, the Jesuits stated: "To be religious today, means to be interreligious meaning, that it in a religious plural world it is inevitable to have positive relationships with believers of other religions." 14

However, it must be noted that these positions are discussed quite controversially in the Church. Pope Benedict XVI rejects the idea of a theological understanding of dialogue, especially regarding dialogue with Islam. $\mathrm{He}$ claims that interreligious dialogue can be practiced only at a cultural level, as the truth of the Divine revelation cannot be negotiated. This diverse and conflictive arguing takes place also in the pastoral realm. However, even the Pope emeritus concedes that dialogue as such is the essence of the Church and is therefore a duty for all Catholics. ${ }^{15}$

\subsection{Thesis II: Interreligious Dialogue Aims at the Common Search for a Better Understanding of the Revealed Christian Truth}

This position can be found in one of the most important documents of the Church on interreligious dialogue: Dialogue and Proclamation (1991). ${ }^{16}$ This document defines dialogue as all the positive and constructive interreligious

\footnotetext{
12 A detailed overview on the development of the Catholic doctrine on interreligious dialogue is given by: Fürlinger, Der Dialog muss weitergehen. There you can find the most important documents published by Pope John Paul II.

13 Johannes Paul II., Ansprache vor Vertretern der Religionen Indiens, n. 4.

14 Citation in: Stranz, Christliches Yoga, p. 101, Translation RP.

15 Benedikt XVI, Ansprache.

16 Pontifical Council for Interreligious Dialogue, Dialogue and Proclamation (DP).
} 
relations with persons and communities of a different faith to improve understanding and enriching each other. These relationships must be practiced in obedience to the truth and in respect of freedom. This does not mean that the Church releases its faith in the fullness of God's revelation in Jesus Christ. But the concept of truth is widened. Rather, $D a P$ states that the Church does not own the Divine truth, but is always "advancing towards the plenitude of divine truth, until eventually the words of God are fulfilled in her."17 Interreligious dialogue therefore can be understood as a way to improve the understanding of the revelation with the help of the others. Together with them, the Church approaches the plenitude of the Divine truth.

Therefore, despite social, cultural and political necessities for dialogue, interreligious dialogue has again theological reasons. From a Catholic perspective, it is neither triggered by contemporary societal challenges nor by state or Church interests only, but by the theological interest of understanding the truth of the revelation more deeply. All the functions of interreligious dialogue - such as combating antisemitism, islamophobia, and religious hostility; strengthening neighbourhood, coexistence, and cohabitation; building human dignity, security and peace; building trust or fostering reconciliation derive their theological foundation from this fundamental theological dimension of interreligious dialogue: to be a way of understanding the Divine truth. Moreover, they are not just functions or ethical or political duties, but an expression of faith. They are normative for inner theological reasons.

As you can imagine, though, also the issue of truth is debated most controversially within the Church. On the one hand, the communicative paradigm of the Second Vatican Council results in the recognition that the truth of the revelation reveals itself only in a dialogical practice - with each other and even with non-believers outside the Church. ${ }^{18}$ From this view, interreligious dialogue can be interpreted as a practice, with which human beings accompany and support each other to find and deepen the understanding of the Divine truth. This includes the willingness to be transformed by interreligious

\footnotetext{
17 DaP n. 31 (quoting Dei Verbum n. 8).

$18 G S$ n. 44: "To promote such exchange, especially in our days, the Church requires the special help of those who live in the world, are versed in different institutions and specialties, and grasp their innermost significance in the eyes of both believers and unbelievers. With the help of the Holy Spirit, it is the task of the entire People of God, especially pastors and theologians, to hear, distinguish and interpret the many voices of our age, and to judge them in the light of the divine word, so that revealed truth can always be more deeply penetrated, better understood and set forth to greater advantage."
} 
encounter ${ }^{19}$ and to learn that the search for a right understanding of the truth is an open and everlasting process. ${ }^{20}$

On the other hand, the Declaration Dominus Iesus (200o), ${ }^{21}$ a controversial declaration of the Catholic Congregation for the Doctrine of the Faith, rejects any kind of reflecting the Divine truth in relative terms, e.g. by justifying religious pluralism not just de facto, but de iure. From this perspective, the plurality of religions must not be legitimized as such theologically. Like Dialogue and Proclamation - but much more impressively - Dominus Iesus highlights the recognition of the uniqueness of the Christian understanding of salvation. The other religions are considered only as a "human treasury of wisdom". ${ }^{22}$ Compared to $D a P$, their theological dignity is downsized.

To conclude: Although there are severe conflicts about the question of how to reflect the Christian truth in the context of religious pluralisation, a Catholic approach must and will debate interreligious dialogue always linked with the question of truth.

\subsection{Theses III: Interreligious Dialogue is Inseparably Linked with Mission, Evangelization and Proclamation}

This linkage is described in Dialogue and Proclamation:

This document states that the evangelizing mission of the Church is a 'single but complex and articulated reality' It indicates the principal elements of this mission: presence and witness; commitment to social development and human liberation; liturgical life, prayer and contemplation; interreligious dialogue; and finally, proclamation and catechesis. Proclamation and dialogue are thus both viewed, each in its own place, as component elements and authentic forms of the one evangelizing mission of the Church. They are both oriented towards the communication of salvific truth. ${ }^{23}$

Interreligious dialogue, therefore, is a dimension of the "evangelizing mission" of the Church, which is based on the universal mission of Jesus Christ. This does not mean that dialogue should be abused as a method to missionize people in a more subtle way. Rather, $D a P$ emphasizes that mission and

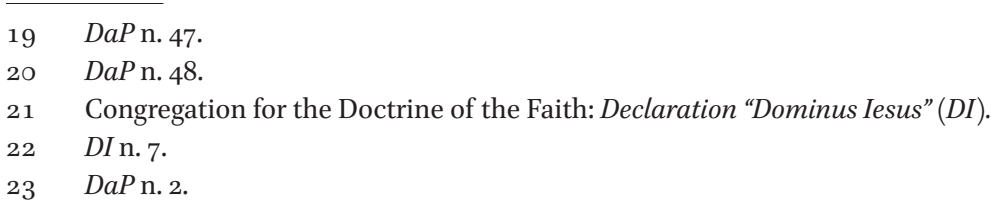


dialogue must be appreciated as two diverse dimensions, that must neither be separated nor mixed. They should be distinguished. Consequently, missionary practice can only take place as dialogue, which results in specific virtues and dispositions, such as openness to the values and convictions of the other, unselfishness, acceptance of differences and of possible contradiction, including the willingness to be transformed by the encounter. ${ }^{24}$ The other way round, the missionary dimension of interreligious dialogue proves itself in the integrity of faith when entering dialogue, which means to remember that God is the origin of any mission and which means to be willing to confess and witness one's own faith. It must be highlighted that in $\mathrm{DaP}$, mission is defined in a very practicaltheological way: Social development and human development are essential dimensions of any evangelizing practice of the Church.

Again, there is no absolute agreement on this understanding of the mission of the Church. Parts of the Church are afraid that this concept is much too wide and relativizes the uniqueness of Christian faith and the Gospel of Jesus Christ as the universal redeemer of all mankind. They refer to the encyclical letter Redemptor Hominis (1979) by Pope John Paul II, which can be seen as the "Magna Charta" of the new relevance that was given to the duty of mission by John Paul II in the 1980s. It emphasized that the mystery of Christ is the basis of the Church's mission and of Christianity. Furthermore, this document expresses deep respect for other religions, and recognizes their spiritual values theologically:

The Council document on non-Christian religions, in particular, is filled with deep esteem for the great spiritual values, indeed for the primacy of the spiritual, which in the life of mankind finds expression in religion and then in morality, with direct effects on the whole of culture. The Fathers of the Church rightly saw in the various religions as it were so many reflections of the one truth, 'seeds of the Word', attesting that, though the routes taken may be different, there is but a single goal to which is directed the deepest aspiration of the human spirit as expressed in its quest for God and also in its quest, through its tending towards God, for the full dimension of its humanity, or in other words for the full meaning of human life. The Council gave particular attention to the Jewish religion, recalling the great spiritual heritage common to Christians and Jews. It also expressed its esteem for the believers of Islam, whose faith also looks to Abraham. ${ }^{25}$

$24 \quad$ DaP 47.

25 Redemptor Hominis n. 11. 
Despite the theological differences concerning the relationship between dialogue and mission, mission is the constitutive framework for interreligious dialogue. As an elementary dimension of mission, interreligious dialogue is therefore an integral part of the mission of the Church and its proclamation. Consequentially, Catholic engagement in social development and human liberation are not mere political actions of the Church, but an important expression of Christian faith and mission - according to DaP not in the sense of abusing politics as a tool for proselytizing, but as a practical and concrete way to proclaim the Gospel.

\subsection{Thesis IV: Interreligious Dialogue is a Way of Life}

The starting point for a practical-theological reflection on interreligious dialogue is not the dogma, but the practice of interreligious dialogue. Practical theology connects findings from social science with the theological tradition, tries to put both approaches into a mutual dialogue and searches for junctions between them. It strives to understand the theological meaning of empirical findings and aims to improve the practice of interreligious dialogue of the Catholic Church.

For this aim, it is helpful to use the practical-theological model of interreligious dialogue as presented in Dialogue and Proclamation. It distinguishes four levels of interreligious dialogue:

a) The dialogue of life, where people strive to live in an open and neighbourly spirit, sharing their joys and sorrows, their human problems and preoccupations.

b) The dialogue of action, in which Christians and others collaborate for the integral development and liberation of people.

c) The dialogue of theological exchange, where specialists seek to deepen their understanding of their respective religious heritages, and to appreciate each other's spiritual values.

d) The dialogue of religious experience, where persons, rooted in their own religious traditions, share their spiritual riches, for instance with regard to prayer and contemplation, faith and ways of searching for God or the Absolute. ${ }^{26}$

These four levels belong together and cannot be separated. From a Catholic perspective, interreligious dialogue is not just an intellectual dialogue, but a relational process, in which all the levels play an equally important role. The level of theological exchange is not the authentic climax of dialogue, but inseparably connected with the other levels. Each level has its respective theological

$26 \quad$ DaP n. 42. 
dignity. The dialogue of life is thus not only a way of applying theological ideas, but the center, where interreligious dialogue finds its origin and must prove its truth. This dialogue-model also takes respect for the sociocultural and sociopolitical context of interreligious dialogue and considers this level as theologically relevant. The four dimensions of dialogue span a net of relationships that only together figure the complex reality of interreligious dialogue. Interreligious dialogue is not a special zone of life: It is a way of life.

\section{Reference to the Empirical Findings on Interreligious Dialogue in Europe}

From a practical-theological point of view, the empirical findings of this issue of $\mathrm{JRAT}^{27}$ can be considered as so-called loci theologici: spaces where old aspects of faith can be remembered or interpreted in a new way, where new dimensions of faith can be detected and even new theological theories can be derived.

When I reflect the research findings in the next section, the four theses of interreligious dialogue from a Catholic-theological perspective will provide the hermeneutical framework. However, I will not apply this framework to judge the research findings but bring these two approaches into a mutual dialogue. I will try to derive hermeneutical, ethical and political consequences from this dialogue. By doing so, I will concentrate on aspects that are usually invisible for both theology and social science. The empirical findings are considered as a possibility to deepen, improve, and correct theological as well as sociological ideas.

The research findings are a gift for the practical-theological disciplines. They enable me to demonstrate that interreligious dialogue never exists as an ideal reality but is always inseparably connected with concrete sociocultural, sociopolitical and historical situations. Moreover, I can demonstrate that these contexts are not just a negligible background, but must be recognized and reflected in their genuine, somehow "incarnated" theological dignity. A social science approach also supports the Church in identifying its role in society and thus in raising self-critical questions: How can the societal and political roles and functions be legitimized theologically? Can they be legitimized at all? On the other hand, the empirical findings can inspire theology and Church to discover new possibilities to realize its mission.

27 Lehmann, Interreligious Dialogue in Context. 
I will give four examples along my theological theses that support these points.

\subsection{Thesis I: Interreligious Dialogue Exists Only in Incarnated Forms}

The research findings demonstrate that the authentic interreligious dialogue of the Church is inseparably linked to societal impulses. Thus, interreligious dialogue is always shaped historically, politically and culturally. Interreligious dialogue is neither a timeless nor an abstract practice. The diversity resulting from this fact is therefore not negligible, but theologically relevant. Theologically spoken: Interreligious dialogue exists only in incarnated forms. The differences must be taken into account in the theological reflection.

In Sweden and the United Kingdom, migration and religious pluralization are the stimulus for interreligious dialogue, which must have an impact on the theological reflection on interreligious dialogue. So do the observations that in Eastern Germany interreligious dialogue takes place in a context of radical secularization, and in the former Yugoslavian countries the consequences of the wars influence the motives, aims and forms of interreligious dialogue. Regarding these differences, different theological aspects will become relevant: in Sweden and the United Kingdom a theology of the plurality of religions could be inspired; in Eastern Germany a theological theory on secularization must be developed; in the former Yugoslavian countries the theology of reconciliation becomes important.

Especially for the German speaking theologies - tending to practice theology as a kind of timeless discipline, perceiving concrete history sometimes only as a stage for theology - the empirical findings should lead to the acceptance that interreligious dialogue has never existed and will never exist as a timeless and pure reality. The research findings force theologians and practitioners of interreligious dialogue to question their own theological debates and identify their own socio-cultural embedding. How does their context influence their own theology and practice? They must also ask for their socio-political interests and pay tribute to them theologically. Theological reflections on interreligious dialogue must ground themselves into the "earthly" reality demonstrated by social science, whether we like it or not.

Vice versa, social science must be reminded that interreligious dialogue is never just a mere reaction to societal developments. Society and politics have a deep impact on interreligious dialogue, and religious people and communities are shaped by them. However, there is no eternal law of social and political dynamics that forces people to react in specific ways. Social science can identify probabilities of human behaviour that theologians must take into account. But social science must be reminded that the practice of interreligious dialogue is 
grounded on free decisions of human beings, influenced by their religious selfunderstanding on the nature of interreligious dialogue. This "inside" dimension must be taken into consideration.

This discovery is relevant also for Churches, as sometimes people committed to interreligious dialogue have forgotten or probably have never reflected the theological dimensions of their practice. They must ask themselves if they have reduced themselves to fulfillers of pragmatic, societal or political interests, forgetting their own religious mission. They must also reflect on whether their interest in interreligious dialogue is stimulated by the hope to either legitimize their existence through interreligious dialogue in secularized countries or to stabilize or regain power in national contexts.

\subsection{Thesis II: Interreligious Dialogue is Always Practiced in a Context of Asymmetric Power Relations}

The research findings demonstrate that the search for truth by means of interreligious dialogue always takes place within historically developed and politically and legally structured relationships of minorities and majorities, e.g. in the context of asymmetric power-relations.

This issue ${ }^{28}$ presents a lot of different examples that prove this thesis: e.g. the hegemonic power of the State Churches in Northern European countries as well as in the United Kingdom; the ethnic or national dimensions of religious self-understanding of the Churches of former Yugoslavia, including their role as ideological enemies before its end; the cooperation of religions in the secular-dominated regions like Eastern Germany to fight for public recognition, or to use interreligious dialogue to combat the LGBT-movement such as in Macedonia.

The empirical findings reveal the duty to reflect the nexus of truth and power, both politically and theologically. Given the Christian importance of fostering justice and peace, which includes a specific option to marginalized groups, asymmetric and unjust power-relations in interreligious dialogue must be restructured. Interreligious dialogue must take care of the establishment of just structures and symmetric power-relations. Taking advantage of hegemonic positions corrupts the proclamation of the Divine truth.

Though it may be disappointing for Christian Churches: The studies demonstrated that neither a theological concept of a relational and communicative truth proposed by the Second Vatican Council in $G s$ nor a decentralized structure like the one of the Danish Church can protect from power imbalances as long as there are asymmetries in the societal and political realm.

28 Lehmann, Interreligious Dialogue in Context. 
In turn, social sciences could be more aware of the impact that the religious claim for truth has on majority and minority relationships within interreligious dialogue. Even if social science must ignore the question of truth methodologically, they should take this impact into consideration in their research. The question of truth has an enormous influence when the recognition of religious plurality is debated in interreligious dialogue. How religious people define their "truth" makes a difference whether accepting the religious other or not. This aspect is not only an academic problem but is highly relevant for social cohesion and peace. Religious institutions can practice interreligious dialogue without recognizing the theological dignity of another religion, which can create severe sociopolitical problems.

It is not without reason that scholars like Peter L. Berger claim the recognition of plurality to be one of the most burning global questions for all religions. ${ }^{29}$ The question of how the Catholic Church interprets its understanding of Divine truth in the context of religious plurality has massive consequences for interreligious peace.

\subsection{Thesis III: Some Political Functions of Interreligious Dialogue can be Appreciated as Dimensions of the Mission of the Church}

The research findings on the political and state functions and interests of interreligious dialogue can be perceived as a dimension of the mission of the Church. Of course, this theological appreciation must be formulated with caution, as the Church must take care not to be abused for the political interests of the powerful. This would be a betrayal of their mission of social liberation and justice. Theological criteria are needed and can be derived from the theological teachings on social justice, responsibility for the poor and marginalized groups, and the protection of human dignity and equality.

The empirical findings present an impressive amount of functions that are fulfilled by the Church: contributing to building up a multicultural, multi-faith, multi-ethnic society like in Sweden; combating racism, anti-Semitism and islamophobia; promoting fundamental humanitarian values like in St. Gallen; preventing radicalism like in Denmark; contributing to social cohesion and the transmission of values as well as influencing the public discourse on Muslims and religion like in the Canton of Vaud; taking responsibility for developing a "safe religion" like in the United Kingdom in the time of the New Labour government. ${ }^{30}$

29 Berger, The many Altars of Modernity.

30 These references refer to the individual contributions to this issue of JRAT: Lehmann, Interreligious Dialogue in Context. 
The list is endless. As the mentioned contributions are highly valued by states and societies, politicians are sometimes even willing to recognize religious self-interests such as the public recognition of the spiritual dimension of the human person (e.g. in the Constitution of Vaud). In some countries also the self-interests of the Churches are accepted: the recognition of religious freedom, including the right to express faith in public space, or preventing legalization of LGBT-interests.

Comparing the political and state-functions with the missionary dimension of the Catholic Church, social sciences could strengthen their focus on the influence of the latter: How does the missionary dimension improve or hinder the willingness to cooperate with the state? Which political interests does the Church have by engaging in interreligious dialogue and how are they argued? Do missionary interests have an impact on the common interest of both the Church and the states supporting social cohesion - and how does the Church imagine social cohesion? Such questions are important, because despite the honorable value of social cohesion, interreligious dialogue can be abused to disguise or whitewash ethnic, social, economic or political conflicts - by both the Church and the states. Furthermore, how does a majority or minority position in interreligious dialogue influence the impact on fostering social cohesion?

The Church, in turn, must reflect if and in how far it is willing to support political or state interests. The aim of promoting a "safe religion" like in the Northern European countries might get into conflict with the prophetical mission of the Church to criticize unjust societal and political structures or inhuman values. As "safe religion" could be interpreted as the promotion of a kind of private religion that does not interfere with secular values, the Catholic Church would contradict its own mission.

The empirical findings also may raise the awareness that political and state interests in countries where majority Churches or State Churches still dominate could force other religions to a kind of structural "churchification". Jewish or Islamic communities could be coerced into adopting the structure of the majority Church, which would contradict their organizational and religious self-understanding.

\subsection{Thesis IV: Again: Interreligious Dialogue is a Way of Life}

The research findings demonstrate the inseparable connection between the different levels of dialogue as a way of life. They mirror a complex net of relationships that already exists: The Interreligious Council in Bosnia-Hercegovina combats religiously argued hate crimes on grassroots-level; religious institutions in East Germany cooperate in a non-religious dominated society to fight for common public interests; theological experts in Denmark and Turkey 
reflect the possibilities and limitations of interreligious dialogue; Christians in St. Gallen open their religious festivals for other religions. Especially in Bosnia-Hercegovina the IRC implemented an impressive structure of interreligious dialogue on all four levels and seems to have had impressive results. Ex negativo, in Macedonia, interreligious dialogue is concentrated on the level of theological representatives and Church leaders but has hardly any impact on the population. This is an indicator of the interrelatedness of the levels of interreligious dialogue. Empirical results prove that a sole theological dialogue makes no difference. In Denmark, the decentralized structure of the interreligious dialogue projects even strengthens the power of the Danish State Church despite an intensive grassroots dialogue.

Maybe the Catholic model of the four levels is a helpful model to analyze interreligious dialogue sociologically as well as theologically. It could help to establish interreligious dialogue as a successful model to live in peace.

\section{Systematic Reflections}

I hope that I have been able to demonstrate how empirical research results can enrich Catholic Theology, and how theological reflection, in turn, can deepen sociological research. Research on sociocultural contexts of interreligious dialogue is not contrary to theological teachings on interreligious dialogue but illuminates its incarnated nature and promotes its further development.

I will finish with some future perspectives that should be considered in further research on interreligious dialogue.

\subsection{Thesis I: Interreligious Dialogue is more than a Social and Political Method or Function}

Interreligious dialogue cannot be reduced to a method or a function. It also is not only a reaction to societal and political processes. Rather, it is rooted in hermeneutic, philosophical, ethical, anthropological, and theological convictions.

Religious plurality is not an objective social fact, driven by secularization or migration. Rather, it is rooted in the uniqueness of any human being. The social and political processes dynamize plurality, but the latter is not caused by them. Interreligious dialogue is rooted in human nature and is therefore an authentic expression of human beings.

I would appreciate if social science research would pay more attention to these theological "inside" dimensions of interreligious dialogue.

This "inside" dimension also plays an important role concerning the questions of the impact of religious concepts of truth and mission. These 
dimensions of self-understanding are quite invisible in the empirical findings. The example of the Turkish scholars ${ }^{31}$ and the Presidency of Religious Affairs in Turkey, who consider interreligious dialogue as a threat for Muslims while at the same time interpreting interreligious dialogue as an instrument to present Islam in its true nature, shows the importance of this perspective on the inner side of interreligious dialogue.

Vice versa, theologians should take seriously the social and political methods, functions, and impacts of interreligious dialogue as theologically significant realities. They should be interpreted as expressions of faith, as diaconal services, or as soteriological "signs of the times". Of course, they also need critical theological evaluation and theological answers.

\subsection{Thesis II: Social Science Research and Theology Suffer from Asymmetric Power Relations}

When social science researches interreligious dialogue without taking religious self-understanding into consideration, they could ask if they themselves suffer from asymmetric power relations in the academic realm. Stressing the secular perspective and ignoring the currently weaker theological perspective may be an indicator for this blind spot. As an example: Ignoring that there are Christian-Orthodox, Jewish and Islamic approaches to interreligious dialogue might distort the empirical findings.

In turn, Catholic reflections on interreligious dialogue could discover many unspoken sociocultural and sociopolitical conflicts in their interfaith projects, if they took social science results seriously. Asymmetric power relations would become visible. Catholic Christians often ignore the fact that Jews and Muslims do not have a binding teaching on interreligious dialogue and engage in dialogue for different reasons and with less power, including a burden of history. Social sciences results reveal the necessity to accept and deal with differences more explicitly.

\subsection{Thesis III: The Church Suffers from a Lack of Reflection on the Theological Arguments for its Political Engagement in Interreligious Dialogue}

Even if most of the secular, political and state interests in interreligious dialogue sound quite honorable, or are even theologically legitimate, the Church must reflect the political dimension of interreligious dialogue more carefully. What is the theological foundation of sociopolitically formatted interreligious dialogue? What are the theological criteria for combating racism and

31 Furat/Er, From Dialogue to Living Together. 
promoting values? Under which conditions is the Church allowed to serve as a representative symbol for national unity? What is a theologically legitimate political mission of interreligious dialogue? What are the limits of fulfilling political tasks in interreligious dialogue? How can the politicization of interreligious dialogue be prevented?

From a Catholic-theological perspective, some of the empirical findings seem rather ambivalent. Some risks of interreligious dialogue may be listed: Fulfilling political interest in interreligious dialogue could lead a Church that suffers from erosion and crisis into temptation to regain power through collaborating with states and governments. Favouring representatives of liberal and inclusive forms of religions that are willing to cooperate with states could discriminate conservative and orthodox forms of religion and stigmatize them as fundamentalist. The research results also demonstrate the danger of politics trying to discipline religion. Remembering the prophetic and anti-authoritarian, anti-state heritage of the biblical tradition, this could be considered problematic. Is it by chance that the Interreligious Think Tank ${ }^{32}$ in Switzerland, a group of Jewish, Christian, and Muslim women, names this aspect and advocates for critical alternatives of interreligious dialogue? They criticize that interreligious dialogue is dominated by men and is strongly politicized.

\subsection{Thesis IV: It is Necessary to Discuss the Possibilities and the Limits of Interreligious Dialogue in the Political Realm}

Throughout Europe, contemporary interreligious dialogue is confronted with high expectations. States, governments, politicians and societies want religious institutions to solve societal, cultural and political problems. Because of the constitutive sociocultural and sociopolitical nature of interreligious dialogue, these expectations can be fulfilled partly through sociopolitical engagement and theological ideas. But the political duties of religious communities have limits, both from the perspective of social science and theology. They can and must not fulfil all societal and political wishes. Problems that have primarily economic, legal, sociocultural or political reasons must be solved economically, legally, socially, and politically. To frame them religiously would be a risk for both society and religion. Religion could be abused to distract from the secular reasons of problems or, vice versa, religion could abuse politics to gain political power. 
Therefore, both theology (of course not only Catholic, but also Protestant, Orthodox, Jewish, and Islamic "theologies") and social science should collaborate more intensively and bring together their different perspectives on interreligious dialogue. This could improve academic clarification, enhance the quality of practicing interreligious dialogue and enable the identification of the possibilities and the limits of interreligious dialogue.

\section{Biography}

Regina Polak (*1967) is the head of the Institute for Practical Theology at the Catholic Theological Faculty of the University of Vienna. She is Assoc.-Prof. for Practical Theology. She studied philosophy, theology and spiritual theology in the interreligious process at the Universities of Vienna and Salzburg. Her research focuses on the following topics: religion in the context of migration and urbanization; religion and values; socio-religious transformation processes in Europe; Christian-Jewish and Christian-Islamic dialogue, and fundamental theological questions of a church in transition. Currently she leads a project on the European Values Study reflecting the relationship between religious and political attitudes from an interdisciplinary perspective. She leads the certificate course "Muslims in Europe" and is currently OsCEPersonal Representative for combating racism, xenophobia and discrimination. She is in charge of the institute's (post) Corona blog: https://theocare. network.

\section{Bibliography}

Ad Gentes: Decree on the Mission Activity of the Church (1965), http://www.vatican. va/archive/hist_councils/ii_vatican_council/documents/vat-ii_decree_19651207_ ad-gentes_en.html, (date of last access: 28.04.2020).

Benedikt XVI: Ansprache an die Mitglieder der "Fondation pour la Recherche et le Dialogue interreligieux et intercultureles, 01.02.2007.

Berger, Peter L.: The many Altars of Modernity. Toward a Paradigm for Religion in a Pluralist Age. Berlin: De Gruyter, 2014.

Congregation for the Doctrine of the Faith: Dominus Iesus, Declaration On the Unity and Salvi Universality of Jesus Christ and the Church. Rome, 2000.

Dehn, Ulrich et al. (eds.): Handbuch Theologie der Religionen. Texte zur religiösen Vielfalt und zum interreligiösen Dialog. Freiburg: Herder 2017. 
Ecclesiam Suam, Encyclical of Pope Paul vi on the Church (1964), http://www.vatican. va/content/paul-vi/en/encyclicals/documents/hf_p-vi_enc_o6o81964_ecclesiam. html (date of last access: 28.04.2020).

Furat, Zişan/Er, Hamit: From Dialogue to Living Together: The Discussions on Inter-Religious Dialogue in Turkey since the Late 199os, in: JRAT 6 (2/2020), pp.

Fürlinger, Ernst: Der Dialog muss weitergehen. Ausgewählte vatikanische Dokumente zum interreligiösen Dialog. Freiburg i.B: Herder, 2009.

Gaudium et Spes, Pastoral Constitution on the Church in the Modern World (1965), http://www.vatican.va/content/paulvi/en/encyclicals/documents/hf_pvi_ enc_o6o81964_ecclesiam.html (date of last access: 28.04.2020).

Interreligiöser Think Tank: https://www.interrelthinktank.ch/ (date of last access: 28.04.2020).

Johannes Paul II: Ansprache vor Vertretern der Religionen Indiens. Madras, 1986, in: Fürlinger, Ernst. Der Dialog muss weitergehen, pp. 297-291.

Lehmann, Karsten (ed.). Interreligious Dialogue in Context. Towards a European Comparison, in: JRAT 6 (2/2020).

Polak, Regina: Migration als Ort der Theologie, in: Polak, Regina: Migration, Flucht und Religion. Praktisch-Theologische Beiträge. Band 1: Grundlagen. Ostfildern: Matthias Grünewald, 2017, pp. 45-81.

Nostra Aetate, the Declaration on the Relation of the Church to Non-Christian Religions (1965), http://www.vatican.va/archive/hist_councils/ii_vatican_council/documents/ vat-ii_decl_19651028_nostra-aetate_en.html (date of last access: 28.04.2020).

Pontifical Council for Interreligious Dialogue: Dialogue and Proclamation, Reflection and Orientations On Interreligious Dialogue and the Proclamation of the Gospel of Jesus Christ. Rome 1991, http://www.vatican.va/roman_curia/pontifical_councils/ interelg/documents/rc_pc_interelg_doc_19051991_dialogue-and-proclamatio_en. html, (date of last access: 28.04.2020).

Redemptor Hominis, Encyclical Letter of John Paul II, Rome 1979, http://www.vatican. va/content/john-paul-ii/en/encyclicals/documents/hf_jp-ii_enc_o4031979_ redemptor-hominis.html (date of last access: 28.04.2020).

Renz, Andreas: Die katholische Kirche und der interreligiöse Dialog. $5^{\circ}$ Jahre „Nostra aetate“. Vorgeschichte, Kommentar, Rezeption. Stuttgart: Kohlhammer, 2014.

Rötting, Martin: Religion in Bewegung. Dialog-Typen und Prozess im interreligiösen Lernen. Berlin: LIT, 2011.

Stranz, Sebastian: Christliches Yoga. Irrweg oder Chance? Norderstedt: Books on Demand, 2017 . 